\title{
DEODORISASI LIMBAH CAIR BATIK MENGGUNAKAN LIMBAH BAGLOG Pleurotus ostreatus DENGAN KOMBINASI VOLUME DAN WAKTU INKUBASI BERBEDA
}

\author{
Heru Teguh Sumarko, Sri Lestari dan Ratna Stia Dewi \\ Fakultas Biologi Universitas Jenderal Soedirman Purwokerto \\ email: heruteguhs@gmail.com
}

\begin{abstract}
ABSTRAK
Limbah cair batik yang dibuang ke lingkungan tanpa diolah terlebih dahulu bersifat toksik, mengakibatkan penurunan kualitas air disekitar lingkungan dan kesehatan dengan munculnya masalah utama seperti bau tidak sedap. Kondisi tersebut diperlukan penanganan agar efek pencemaran rendah atau menjadikan limbah cair batik tidak toksik. Penelitian tentang pengelolaan limbah cair batik berupa deodorisasi menggunakan limbah baglog Pleurotus ostreatus dengan kombinasi volume dan waktu inkubasi berbeda telah diujikan. Tujuan penelitian adalah untuk mengetahui kemampuan limbah baglog $P$. ostreatusdengan kombinasi volume dan waktu inkubasi berbeda dalam mendeodorisasi limbah cair batik, dan untuk mengetahui perlakuan yang terbaik dalam mendeodorisasi limbah cair batik menggunakan limbah baglog $P$. ostreatus dengan kombinasi volume dan waktu inkubasi berbeda. Hasil penelitian menunjukkan bahwa limbah baglog P. ostreatus dengan kombinasi volume dan waktu inkubasi berbeda mampu mendeodorisasi limbah cair batik. Hasil terbaik berupa penurunan skala bau 3 (tidak bau) yang diikuti persentase penurunan nilai BOD sebesar 93,95\% (3301 mg/l menjadi $200 \mathrm{mg} / \mathrm{l}$ ) dan COD 79,66\% $(15200 \mathrm{mg} / \mathrm{l}$ menjadi $3120 \mathrm{mg} / \mathrm{l})$ pada perlakuan $100 \mathrm{ml}$ volume limbah cair batik dan 96 jam waktu inkubasi.
\end{abstract}

Kata kunci: Limbah Cair Batik, Deodorisasi, Limbah Baglog Pleurotus ostreatus.

\section{DEODORIZATION OF BATIK SEWAGE USING BAGLOG Pleurotus ostreatus's WASTE WITH COMBINATION OFDIFFERENT VOLUME AND INCUBATION TIME}

\begin{abstract}
Batik sewage discharged into the environment without being processed first will become toxic, reducing the quality of water environment and health resulting a main problem, such as unpleasant smells. This condition requires treatment to reduce contamination or removing batik sewage's toxicity. A study about batik sewage procession in form of deodorization using baglog Pleurotus ostreatus waste with combination of volume and incubation time were proposed. The aim of this study is to find out the baglog $P$. ostreatus waste's ability in deodoration for batik sewage with combination of different volume and incubation time, and to find out the best treatment for batik sewage deodorization using baglog $P$. ostreatus waste with combination of different volume and incubation time. The study's results showed that baglog $P$. ostreatus waste with combination of different volume and incubation time can be used as deodoration for batik sewage. The best results are reduction in odor scale by 3 (does not stink) followed by percentage value reduction in BOD as much as 93,95\% (from $3301 \mathrm{mg} / l$ to $200 \mathrm{mg} / \mathrm{l}$ ) and
\end{abstract}


COD in the amount of 79,66\% (from $15200 \mathrm{mg} / \mathrm{l}$ to $3120 \mathrm{mg} / \mathrm{l}$ ), which were acquired at $100 \mathrm{ml}$ batik sewage volume and 96 hour incubation time treatment.

\section{Key Words: Batik Sewage, Deodorization, Baglog Pleurotus ostreatuswast}

\section{Pendahuluan}

Industri batik merupakan salah satu bidang industri yang sangat pesat berkembang di Indonesiautamanya di Banyumas, baik yang dikelola dalam skala besar maupun kecil. Terlepas dari peranannya sebagai komoditi ekspor yang memberikan dampak positif bagi devisa negara, ternyata industri batik jugamemberikan dampak negatif berupa limbah cair batikyang menyebabkan penurunan kualitas lingkungan dan kesehatan. Limbah cair batik bersifat toksik dan mencemari lingkungan apabila tidak diolah terlebih dahulu sebelum dibuang. Masalah utama yang ditimbulkan oleh limbah cair batik adalah bau tidak sedap. Menurut Budiawan, (2001) bau merupakan salah satu parameter pencemaran yang merupakan sumber gangguan fisik dan nonfisik serta penyebarannya terjadi melalui udara sebagai mediumnya.

Menurut Astirin dan Winarno, (2000) pencemaran air oleh industri batik padaumumnya bersumber dari proses pencelupan warna pertama,penghilangan lilin untuk mendapatkan warna yang kedua, ketiga dan seterusnya (jika diperlukan) dariproses pelorodan dalam air mendidih, dan sumber pencemar lain dari proses pencucian. Bentuk pencemar lain pada industri batik berupa fenol yang berasal dari lilin/malam serta penggunaan bahan pembantu seperti minyak tanah.

Kasam et al.,(2009) menambahkan bahwa limbah cair batik mengandung bahan organik tinggi yang disebabkan oleh sisa-sisa proses pembatikan. Proses pencelupan warna merupakan penyumbang sebagian kecil limbah organik, namun penyumbang warna yang kuat. Proses persiapan, yaitu proses nganji atau mengkanjimenyumbang zat organik yang banyak mengandung zat padat tersuspensi. Zat padat tersuspensi apabila tidak segera diolah akan menimbulkan bau yang tidak sedap. Bau tidak sedap yang timbul dapat digunakan untuk menilai kandungan BOD (Biological Oxygen Demand) dan COD (Chemical Oxygen Demand). Senyawa organik dan anorganik yang banyak terdapat dalam limbah cair batik berupa karbohidrat, protein, lemak, surfaktan dan zat organik aromatik seperti warna, zat pencelupan, alkali, asam dan garam.

Bau tidak sedap pada limbah cair batik disebabkan karena meningkatnya nilai BOD dan COD. Hal tersebut disebabkan kandungan bahan organik yang tinggi terdegradasi secara anaerob oleh mikroorganisme (Astirin Dan Winarno, 2000). Nilai BOD pada limbah cair tekstil dan batik dilaporkan mencapai 1099,22 mg/l (Rambe, 2008) dan COD berkisar $1310 \mathrm{mg} / \mathrm{l}$ (Malik, 2003). Kadar tersebut melebihi baku mutu yang telah ditetapkan oleh Pemerintah Daerah Provinsi Jawa Tengah berdasarkan Keputusan No.5 Tahun 2012 Tentang Baku Mutu Limbah Cair Tekstil dan Batik yaitu $60 \mathrm{mg} / \mathrm{l}$ dan $150 \mathrm{mg} / \mathrm{l}$ (Pemprov Jateng, 2012). Nilai BOD dan COD limbah cair batik yang semakin tinggi, akan menyebabkan semakin bau limbah cair batik tersebut.

Ada 26 jenis senyawa yang menjadi sumber bau yang diemisikan dari kegiatan industri. Tiga dari 26 jenis senyawa tersebut dijadikan sebagai parameter kebauan yaitu metil merkaptan $\left(\mathrm{CH}_{3} \mathrm{SH}\right)$, amoniak $\left(\mathrm{NH}_{3}\right)$, dan hidrogen sulfida $\left(\mathrm{H}_{2} \mathrm{~S}\right)$. Kebauan adalah bau yang tidak diinginkan dalam kadar dan waktu tertentu yang dapat mengganggu 
kesehatan manusia dan kenyamanan lingkungan (Kepmen No.50/MenLH/II/ 1996 dalam Kosasih, 2003).

Berbagai upaya pengolahan limbah telah dilakukan baik secara kimia dan fisika. Namun pengolahan tersebut tidak ramah lingkungan, mahal dan sulit diaplikasikan, sehingga diperlukan alternatif pengolahan limbah yang murah, mudah dan ramah lingkungan. Salah satu alternatif pengolahan limbah ialah secara biologi menggunakan jamur pelapuk putih (Awaludin et al., 2001) melalui teknik biodeodorisasi. Jamur dipilih karena mempunyai kemampuan transformasi, yaitu merubah bahan kimia berbahaya pada limbah menjadi bentuk yang kurang atau tidak berbahaya. Nasreen et al., (2007) dan Singh, (2006) melaporkan salah satu jamur yang mampu menghilangkan bau pada limbah industri tekstil adalah jamur pelapuk putih. Jamur pelapuk putih yang digunakan adalah jamur Pleurotus ostreatus yang masih terdapat pada limbah baglog P. ostretus dalam bentuk miselium jamur.

$P$. ostreatus memproduksi enzim ekstraseluler seperti mangan peroksidase (Mn-P) dan lakase (Lac) berdasar pola enzim ligninolitik yang dihasilkan. Mn-P dan Lac bertanggung jawab terhadap biodegradasi polutan organik karena memiliki aktivitas katalitik terhadap berbagai jenis substrat. (Hatakka, 1994; Thurston, 1994). Lac pada $P$. ostreatus mampu mendegradasi substrat nonfenolik dengan mengoksidasinya (Palmieri et al., 2000). Bioremediasi dan biodegradasi polutan organik dilakukan secara aerobik menggunakan enzim ekstraseluler yang dihasilkannya (Howard et al., 2003; Dhouib, 2005).

\section{Limbah baglog $P$. ostreatus} adalah medium pertumbuhan jamur $P$. ostreatus yang sudah habis masa tanamnya. Limbah baglog $P$. ostreatus berpotensi sebagai bahan penjerap karena mengandung selulosa dan hemiselulosa.
Menurut Sukarta, (2008) selulosa dan hemiselulosa pada serbuk gergaji dari kayu albasia berpotensi sebagai bahan penjerap (adsorben) pada proses adsorpsi. Menurut Rosdiana, (2006) adsorpsi yakni proses pejerapan suatu zat oleh zat lainnya, yang hanya terjadi pada permukaan. Menurut Romsiyah, (2012) limbah baglog $P$. ostreatus memiliki kandungan selulosa sebesar $34,44 \%$ dan mampu mengadsorpsi zat organik aromatik seperti zat warna limbah cair batik dengan persentase dekolorisasi $76,25 \%$.

Kemampuan limbah baglog $P$. ostreatusmenjerap kandungan organik lain pada limbah cair batik mengikuti adsorpsi zat warna (zat organik aromatik) melalui hubungan atau kontak antara limbah baglog $P$. ostreatus yang mengandung selulosa, hemiselulosa dengan limbah cair batik. Menurut Aziziah, (2008) bahwa bahan penjerap dalam adsorpsi adalah suatu bahan yang dapat menjerap molekul kecil termasuk kandungan limbah tekstil tersebut.

Proses adsorpsi limbah baglog $P$. Ostreatus merupakan sistem nonenzimatik yang diharapkan mampu meningkatkan kinerja miselium jamur $P$. Ostreatus pada proses deodorisasi melalui sistem enzimatik. Perbedaan volume limbah cair batik dan waktu inkubasi pada penelitian digunakan untuk mengetahui pengaruh-nya terhadap proses deodorisasi. Hal tersebut diperlukan untuk mendapatkan informasi komposisi yang tepat berapa volume limbah cair batik dan lama waktu inkubasi yang optimum dalam mendeodorisasi limbah cair batik. Penelitian mengenai deodorisasi menggunakan jamur pelapuk putih telah banyak dilakukan seperti Aziziah, (2008) melaporkan bahwa formula jamur pelapuk putih Omphalina sp. memiliki kemampuan dalam mendeodorisasi limbah cair industri tekstil dengan hasil terbaik pada jam ke-6 yang diikuti 
penurunan COD sebesar 76,76\% (1734 ppm menjadi 403 ppm). Negishi dan Negishi, (1999) melaporkan jamur Agaricus bisporus dari kelas Basidiomycetes memiliki aktivitas deodorisasi tertinggi terhadap bau metil merkaptan dari lingkungan mencakup bau mulut melalui proses mengunyah dengan presentase deodorisasi $100 \%$. Negishi et al., (2000) menambahkan jamur Boletus subvelutipes dari kelas Basidiomycetes mampu mendeodorisasi bau bawang putih penyebab bau mulut. Komponen zat penyebab bau pada bawang putih yaitu methanethiol dan allylthiol dengan persentase deodorisasi $100 \%$.

Romsiyah, (2012) melaporkan bahwa $25 \mathrm{~g}$ limbah baglog $P$. ostreatus yang digunakan untuk mengolah limbah cair batik menghasilkan persentase dekolorisasi tertinggi sebesar 76,25\% dengan variasi limbah baglog yang digunakan 5 g, 10 g, 15 g, 20 g, 25 g, 30 $\mathrm{g}, 35 \mathrm{~g}$ dengan masing-masing untuk setiap perlakuan $50 \mathrm{ml}$ limbah cair batik. Sorta, (2013) menambahkan limbah baglog $P$. ostreatus optimum mendekolorisasi limbah cair batik pada waktu inkubasi 72 jam. Kemampuan limbah baglog $P$. ostreatus dalam mendekolorisasi limbah cair batik diduga berbanding lurus dalam mendeodorisasi.

Penelitian deodorisasi terhadap limbah cair batik menggunakan limbah baglog $P$. ostreatus sebagai alternatif pengolahan limbah belum pernah dilakukan. Penelitian bertujuan untuk mengetahui kemampuan limbah baglog $P$. ostreatus dengan kombinasi volume dan waktu inkubasi berbeda dalam mendeodorisasi limbah cair batik, dan mengetahui perlakuan yang terbaik dalam mendeodorisasi limbah cair batik.

\section{METODE PENELITIAN}

Penelitian dilakukan di Laboratorium Mikologi dan Fitopatologi Fakultas Biologi UNSOED selama dua bulan.
Sampel limbah cair batik diperoleh dari industri batik di Desa Kauman, Kecamatan Sokaraja, Kabupaten Banyumas, Jawa Tengah. Limbah baglog $P$. ostreatus diperoleh dari tempat budidaya jamur $P$. ostreatus Desa Pabuaran, Kecamatan Baturaden, Kabupaten Banyumas, Jawa Tengah. Penelitian dilakukan secara survei dan eksperimental. Survei dilakukan dengan menggunakan kuisioner yang bersifat tertutup terhadap 30 responden. Responden merupakan panelis non standar sesuai SNI 01-2346-2006 yang dimodifikasi. Penelitian secara eksperimental menggunakan Rancangan Acak Lengkap (RAL) dengan 12 perlakuan dan 3 kali ulangan. Perlakuan yang diujikan adalah :

$\mathrm{P}_{1}=25 \mathrm{~g}$ limbah baglog P. ostreatus +25 ml volume limbah cair batik + waktu inkubasi 48 jam

$\mathrm{P}_{2}=25 \mathrm{~g}$ limbah baglog P. ostreatus + $50 \mathrm{ml}$ volume limbah cair batik + waktu inkubasi 48 jam

$\mathrm{P}_{3}=25 \mathrm{~g}$ limbah baglog P. ostreatus + $75 \mathrm{ml}$ volume limbah cair batik + waktu inkubasi 48 jam

$\mathrm{P}_{4}=25 \mathrm{~g}$ limbah baglog P. ostreatus + $100 \mathrm{ml}$ volume limbah cair batik + waktu inkubasi 48 jam

$\mathrm{P}_{5}=25 \mathrm{~g}$ limbah baglog P. ostreatus + $25 \mathrm{ml}$ volume limbah cair batik + waktu inkubasi 72 jam

$\mathrm{P}_{6}=25 \mathrm{~g}$ limbah baglog P. ostreatus + $50 \mathrm{ml}$ volume limbah cair batik + waktu inkubasi 72 jam

$\mathrm{P}_{7}=25 \mathrm{~g}$ limbah baglog P. ostreatus + $75 \mathrm{ml}$ volume limbah cair batik + waktu inkubasi 72 jam

$\mathrm{P}_{8}=25 \mathrm{~g}$ limbah baglog P. ostreatus + $100 \mathrm{ml}$ volume limbah batik + waktu inkubasi 72 jam

$\mathrm{P}_{9}=25 \mathrm{~g}$ limbah baglog P. ostreatus + $25 \mathrm{ml}$ volume limbah cair batik + waktu inkubasi 96 jam

$\mathrm{P}_{10}=25 \mathrm{~g}$ limbah baglog $P$. ostreatus + $50 \mathrm{ml}$ volume limbah cair batik + waktu inkubasi 96 jam 
$\mathrm{P}_{11}=25 \mathrm{~g}$ limbah baglog P. ostreatus + $75 \mathrm{ml}$ volume limbah cair batik + waktu inkubasi 96 jam

$\mathrm{P}_{12}=25 \mathrm{~g}$ limbah baglog P. ostreatus + $100 \mathrm{ml}$ volume limbah cair batik + waktu inkubasi 96 jam

Persiapan unit penelitian dilakukan dengan menempatkan limbah cair batik ke dalam botol uji sebanyak $25 \mathrm{ml}, 50 \mathrm{ml}, 75$ $\mathrm{ml}$ dan $100 \mathrm{ml}$. Selanjutnya limbah baglog $P$. ostreatus dipotong - potong dadu, ditimbang dengan berat $25 \mathrm{~g}$ dan dimasukkan dalam botol uji berdasarkan taraf perlakuan yang dicobakan. Kemudian diinkubasi menggunakan shaker resiprokal dan diuji tingkat kebauannya berdasarkan SNI 01-23462006 yang dimodifikasi. Penentuan kebauan diujikan kepada 30 orang panelis non standar dengan skala uji yakni dari 19. Kemudian dilanjutkan dengan pengukuran parameter limbah cair batik sebelum dan sesudah perlakuan seperti BOD dan COD (APHA, 1995), pengukuran $\mathrm{pH}$ (SNI 06-6989.11-2004) dan suhu (SNI 06-6989.23-2005). Penentuan persentase BOD dan COD limbah cair batik mengacu pada Rani et al.,(2011) yang dimodifikasi dengan rumus masing-masing untuk BOD dan COD:

$\%$ BOD $=\frac{\text { nilai BOD awal }- \text { nilai BOD akhir }}{\text { Nilai BOD awal }} \times 100 \%$

$\% \mathrm{COD}=\frac{\text { nilai COD awal }- \text { nilai COD akhir }}{\text { Nilai COD awal }} \times 100 \%$

Data deodorisasi dianalisis dengan menggunakan analisis deskriptif (Santoso, 2002). Data penurunan persentase BOD dan COD dianalisis dengan uji ANOVA yang sebelumnya ditransformasi ke dalam bentuk arc $\sin \sqrt{ } x$ kemudian dilanjutkan dengan uji BNJ dengan tingkat kesalahan $1 \%$ atau $5 \%$ untuk mengetahui perbedaan antar perlakuan (Sokal dan Rohl, 1981).

\section{HASIL DAN PEMBAHASAN}

\section{Penentuan Kemampuan Deodorisasi Limbah Cair Batik Berupa Penurunan Skala Bau}

Hasil penelitian terhadap tingkat kebauan menunjukkan bahwa limbah baglog $P$. ostreatus dengan kombinasi volume dan waktu inkubasi berbeda mampu mendeodorisasi limbah cair batik melalui penurunan skala bau pada limbah cair batik. Skala bau limbah cair batik sebelum perlakuan adalah 7 (bau) dan setelah perlakuan berkisar antara 6 (agak bau) sampai 3 (tidak bau). Kemampuan deodorisasi oleh limbah baglog $P$. ostreatus dengan perlakuan yang diujikan selengkapnya disajikan pada Gambar 1 .

Gambar 1 menunjukkan kemampuan limbah baglog P. ostreatus dengan kombinasi volume dan waktu inkubasi berbeda dalam menurunkan skala bau limbah cair batik. Penurunan skala bau pada $\mathrm{P}_{1}$ sampai $\mathrm{P}_{12}$ memberikan hasil yang berbeda. Hasil terbaik dengan skala bau 3 (tidak bau) diperoleh pada perlakuan $\mathrm{P}_{12}$. Terjadinya proses deodorisasi karena adanya proses adsorpsi sebagai sistem non-enzimatik dan proses absorpsi sebagai sistem enzimatik berupa kemampuan penghilangan senyawa penyebab bau dan degradasi polutan organik oleh miselium jamur $P$. ostreatus melalui aktivitas katalitik menggunakan enzim ekstraseluler (Mn-P dan Lac). Menurut Yasuda dan Arakawa, (1995); Negishi dan Negishi, (1999) mekanisme deodorisasi dengan jamur dari kelas Basidiomycetes terjadi secara enzimatik dan non-enzimatik. Hatakka, (1994) menjelaskan jamur $P$. ostreatusyang tergolong jamur kelas Basidiomycetes adalah jamur yang memproduksi multi enzim ekstraseluler Mn-P dan Lac. Proses deodorisasi pada penelitian diduga sama karena menggunakan agen biologis yang sama yaitu jamur dan adanya adsorben seperti pada penelitian Negishi et al., (2000); Tamaki et al., (2007). 


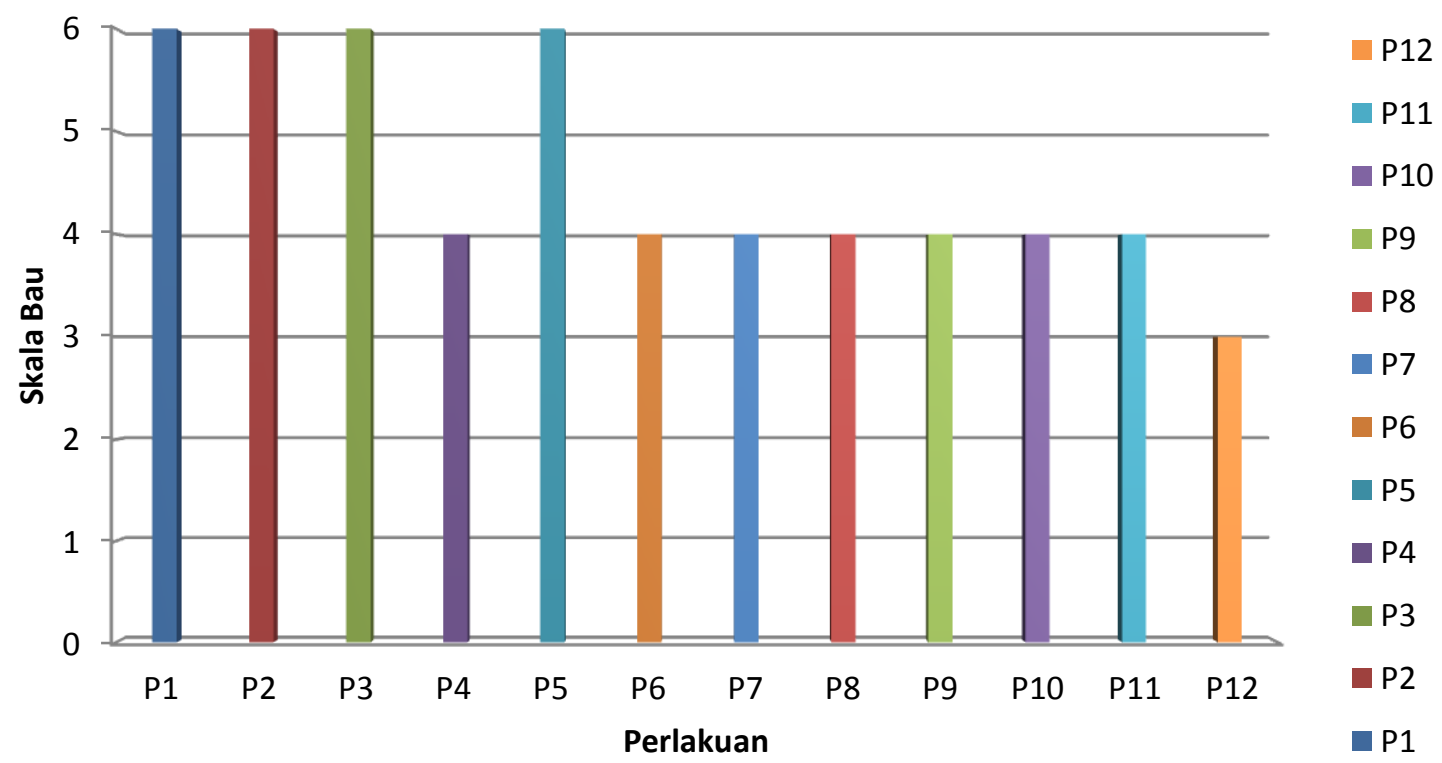

\section{Gambar 1.Kemampuan DeodorisasiLimbah Cair Batik Berupa Penurunan Skala BauLimbah Cair Batik}

Keterangan :

$$
\begin{aligned}
& \mathrm{P}_{1}=25 \mathrm{~g} \text { limbah baglog } P . \text { ostreatus }+25 \mathrm{ml} \text { volume limbah cair batik }+48 \mathrm{jam} \\
& \mathrm{P}_{2}=25 \mathrm{~g} \text { limbah baglog } P . \text { ostreatus }+50 \mathrm{ml} \text { volume limbah cair batik }+48 \mathrm{jam} \\
& \mathrm{P}_{3}=25 \mathrm{~g} \text { limbah baglog } P . \text { ostreatus }+75 \mathrm{ml} \text { volume limbah cair batik }+48 \mathrm{jam} \\
& \mathrm{P}_{4}=25 \mathrm{~g} \text { limbah baglog } P . \text { ostreatus }+100 \mathrm{ml} \text { volume limbah cair batik }+48 \mathrm{jam} \\
& \mathrm{P}_{5}=25 \mathrm{glimbah} \text { baglog } P . \text { ostreatus }+25 \mathrm{ml} \text { volume limbah cair batik }+72 \mathrm{jam} \\
& \mathrm{P}_{6}=25 \mathrm{~g} \text { limbah baglog } P . \text { ostreatus }+50 \mathrm{ml} \text { volume limbah cair batik }+72 \mathrm{jam} \\
& \mathrm{P}_{7}=25 \mathrm{~g} \text { limbah baglog P. ostreatus }+75 \mathrm{ml} \text { volume limbah cair batik }+72 \mathrm{jam} \\
& \mathrm{P}_{8}=25 \mathrm{glimbah} \text { baglog } P . \text { ostreatus }+100 \mathrm{ml} \text { volume limbah cair batik }+72 \mathrm{jam} \\
& \mathrm{P}_{9}=25 \mathrm{~g} \text { limbah baglog } P . \text { ostreatus }+25 \mathrm{ml} \text { volume limbah cair batik }+96 \mathrm{jam} \\
& \mathrm{P}_{10}=25 \mathrm{~g} \text { limbah baglog } P . \text { ostreatus }+50 \mathrm{ml} \text { volume limbah cair batik }+96 \mathrm{jam} \\
& \mathrm{P}_{11}=25 \mathrm{~g} \text { limbah baglog } P . \text { ostreatus }+75 \mathrm{ml} \text { volume limbah cair batik }+96 \mathrm{jam} \\
& \mathrm{P}_{12}=25 \mathrm{~g} \text { limbah baglog } P . \text { ostreatus }+100 \mathrm{ml} \text { volume limbah cair batik }+96 \mathrm{jam}
\end{aligned}
$$

Proses adsorpsi (penjerapan) pada limbah cair batik oleh limbah baglog $P$. ostreatus dilakukan oleh selulosa dan hemiselulosa. Mekanisme tersebut terjadi melalui penjerapan molekul yang lebih kecil dalam struktur senyawanya yang berongga dan zat yang mengandung gugus tertentu. Mekanisme penjerapan menyebabkan berkurang atau hilangnya kandungan senyawa organik dan anorganik pada limbah cair batik. Romsiyah, (2012) menyatakan limbah baglog $P$. ostreatus masih mengandung selulosa sebesar $34,44 \%$ yang mampu mendekolorisasi limbah cair batik. Suwarsa, (1998) menambahkan bahwa zat warna tekstil mengandung gugusgugus yang dapat bereaksi dengan gugus $\mathrm{OH}$ pada selulosa sehingga wana dapat terikat adsorben.

Proses adsorpsi merupakan proses penjerapan yang hanya terjadi pada permukaan adsorben (Rosdiana, 2006). Proses tersebut menyebabkan terjadinya suatu ikatan kimia fisika antara substansi dengan penjerapnya (Mufrodi et al., 2008). Kemampuan limbah baglog $P$. ostreatus dalam menjerap warna merupakan kemampuan dalam menjerap zat organik aromatik pada limbah cair batik (Gambar 2). 


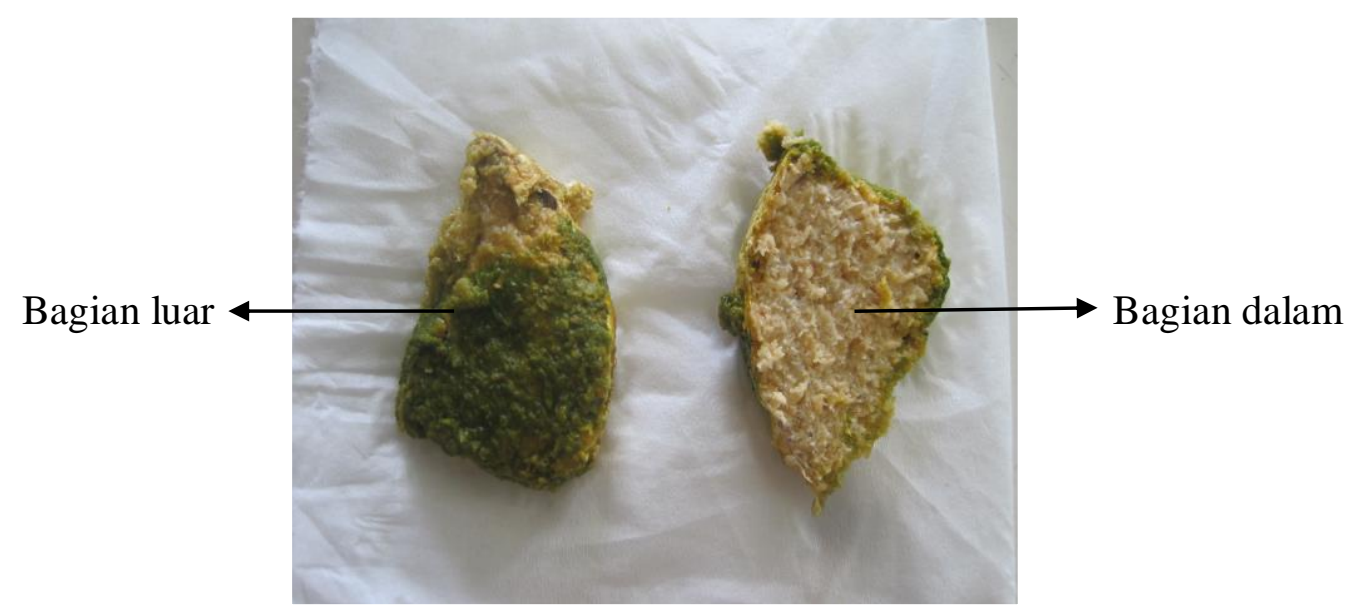

Gambar 2. Adsorpsi limbah cair batik yang hanya terjadi pada permukaan adsorben limbah baglog P. ostreatus

Limbah baglog P. ostreatus juga menjerap kandungan senyawa organik dan anorganik lainnya serta komponen fenolik pada limbah cair batik. Kemampuan tersebut mempengaruhi daya deodorisasi terhadap limbah cair batik. Proses deodorisasi selanjutnya terjadi secara absorpsi sebagai sistem enzimatik. Menurut Sigit, (2008) mangan peroksidase (Mn-P) mampu mengoksidasi komponen fenolik dan nonfenolik. De Jong et al., (1994) menjelaskan enzim Mn-P adalah enzim yang mengaktifkan proses oksidasi dan dapat berdifusi ke dalam substrat. Palmieri et al., (2000) menyatakan enzim ekstraseluler Lac yang diproduksi $P$. ostreatus mampu mendegradasi substrat fenolik dan nonfenolik melalui proses oksidasi. Hatakka, (1994) enzim Lac merupakan enzim yang banyak mengandung tembaga oksidase dan mempunyai kemampuan untuk mengoksidasi senyawaan fenol.

Aktivitas enzimatik tersebut menyebabkan senyawa organik pada limbah cair batik dimanfaatkan sebagai sumber energi dan nutrisi alternatif miselium $P$. ostreatus melalui aktivitas katalitik sehingga zat warna (zat organik aromatik) dan kandungan organik lainnya serta komponen fenolik pada limbah cair batik terdegradasi. Tavcar, (2006) menyatakan jamur pelapuk putih mampu menggunakan zat warna sebagai sumber karbon yang menyebabkan zat warna berkurang atau habis. Kemungkinan mekanisme tersebut adalah oksidasi gugus kromofor seperti yang dikemukakan oleh Yaropolov et al., (1994) bahwa Lac mampu mengoksidasi ikatan azo $(-\mathrm{N}=\mathrm{N}-)$ yang merupakan gugus kromofor menjadi gugus $-\mathrm{OH}$ dan $\mathrm{N}_{2}$. Menurut Sigit, (2008) enzim ekstraseluler adalah biokatalisator efektif dalam mempercepat reaksi kimia yang berfungsi merubah nutrien yang terdapat disekitarnya sehingga memungkinkan nutrien tersebut untuk memasuki sel. Campbell et al., (2002) menyatakan enzim adalah protein katalitik dan mempunyai dampak metabolik yang sangat besar dengan cara berfungsi terus menerus dalam siklus katalitik.Menurut Yuniawati, (2006) aktivitas degradasi berhubungan dengan pembentukan miselium baru. Pertumbuhan miselium jamur memerlukan karbon dan nitrogen yang diperoleh dari degradasi kandungan substrat. Bonnen et al., (1994) menjelaskan bahwa peningkatan aktivitas enzim Mn-P dan Lac terjadi pada saat pembentukan miselia dan mencapai maksimum pada saat perkembangan primordia jamur (Gambar 3). 


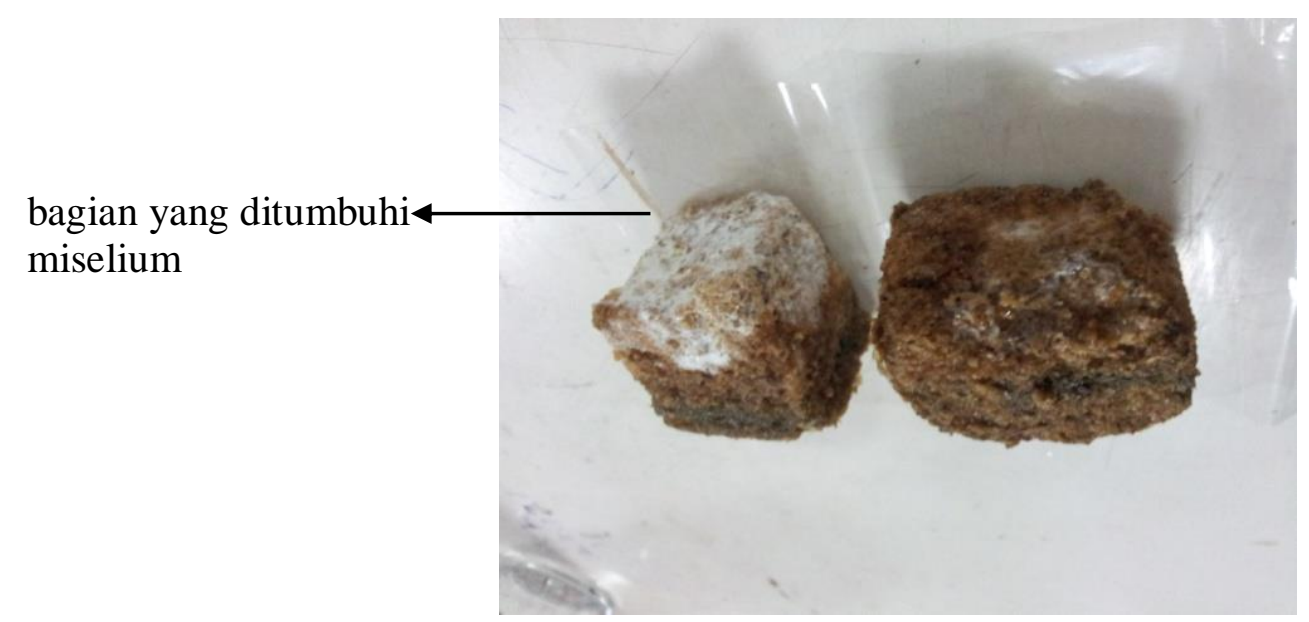

Gambar 3. Limbah baglog P. ostreatus yang ditumbuhi miselium P. ostreatus selama masa inkubasi

Aktivitas enzimatik oleh enzim ekstraseluler pada $P$. ostreatus juga memutus ikatan kovalen pada masingmasing zat penyebab bau yang dihasilkan oleh limbah cair batik seperti metil merkaptan $\left(\mathrm{CH}_{3} \mathrm{SH}\right)$, hidrogen sulfida $\left(\mathrm{H}_{2} \mathrm{~S}\right)$, amoniak $\left(\mathrm{NH}_{3}\right)$, sehingga menjadi zat yang tidak berbau dan tidak berbahaya. Menurut Campbell et al., (2002) ketika tempat aktif enzim telah mengikat substrat melalui kecocokan terinduksi, enzim dapat menekan molekul-molekul substrat, meregang dan membengkokkan ikatan kimiawi penting yang harus diputuskan selama aktivitas enzimatik dengan mengkatalisisnya. Choi, (1997) menjelaskan penghilangan bau oksidatif pada metil merkaptan $\left(\mathrm{CH}_{3} \mathrm{SH}\right)$ menghasilkan dimetil disulfida $\left(\mathrm{CH}_{3} \mathrm{SSCH}_{3}\right)$ dan $\mathrm{H}_{2} \mathrm{O}, \mathrm{H}_{2} \mathrm{~S}$ menghasilkan unsur sulfur (S) dan $\mathrm{H}_{2} \mathrm{O}$. Hedge and Berra, (2002) menjelaskan amoniak $\left(\mathrm{NH}_{3}\right)$ yang mengalami proses oksidasi akan menghasilkan nitrogen $\left(\mathrm{N}_{2}\right)$ dan $\mathrm{H}_{2} \mathrm{O}$.

Adapun penyebab bau yang muncul pada limbah cair batik seperti metil merkaptan $\left(\mathrm{CH}_{3} \mathrm{SH}\right)$, hidrogen sulfida $\left(\mathrm{H}_{2} \mathrm{~S}\right)$, amoniak $\left(\mathrm{NH}_{3}\right)$ disebabkan oleh penggunaan pewarna, kanji, lilin/malam dan bahan tambahan seperti minyak tanah pada proses industri batik. Menurut Groff, (1991) limbah cair industri tekstil menghasilkan bau metil merkaptan $\left(\mathrm{CH}_{3} \mathrm{SH}\right)$. CPCB, (2008) menambahkan bahwa pewarna yang digunakan dalam industri tekstil adalah sumber utama polusi bau dan menghasilkan senyawa yang berbau seperti amoniak $\left(\mathrm{NH}_{3}\right)$, hidrogen sulfida $\left(\mathrm{H}_{2} \mathrm{~S}\right)$, dan metil merkaptan $\left(\mathrm{CH}_{3} \mathrm{SH}\right)$.

Kemampuan deodorisasi menggunakan limbah baglog $P$. ostreatus dipengaruhi oleh variasi volume limbah cair batik dan waktu inkubasi yang diujikan. Hal tersebut dapat terlihat dalam penurunan skala bau yang berbeda. Kondisi tersebut dapat diakibatkan karena tidak optimalnya limbah baglog $P$. ostreatus dalam proses adsorpsi (sistem non-enzimatik) dan absorpsi (sistem enzimatik) terhadap limbah cair batik. Limbah baglog P. ostreatus tidak sepenuhnya menjerap senyawa organik dan anorganik yang terkandung dalam limbah cair batik pada volume $25 \mathrm{ml}, 50$ $\mathrm{ml}, 75 \mathrm{ml}$. Skala bau yang dihasilkan berkisar antara 6 (agak bau) sampai 4 (agak tidak bau) karena luas permukaan padatan limbah baglog P. ostreatus per satuan volume limbah cair batik yang kecil dalam proses adsorpsi. Menurut Atkins, (1999) salah satu faktor yang mempengaruhi proses adsorpsi adalah luas permukaan.

Luas permukaan padatan limbah baglog $P$. ostreatus yang digunakan apabila semakin kecil, maka akan semakin kecil juga yang teradsorpsi limbah cair batik dan berpengaruh pada 
optimalisasi absorpsi oleh miselium jamur $P$. ostreatus. Kemampuan deodorisasi yang tinggi pada volume limbah cair batik $100 \mathrm{ml}$. Skala bau berkisar antara 4 (agak tidak bau) sampai 3 (tidak bau), yang disebabkan besarnya penggunaan luas permukaan padatan limbah baglog $P$. ostreatus per satuan volume limbah cair batik. Jika semakin besar luas permukaan padatan limbah baglog $P$. ostreatus yang digunakan, maka semakin besar teradsorpsinya limbah cair batik dan mengakibatkan optimalisasi proses absorpsi oleh miselium jamur $P$. ostreatus. Penurunan skala bau juga memperlihatkan kemampuan deodorisasi oleh limbah baglog $P$. ostreatus semakin tinggi seiring lamanya waktu inkubasi. Penurunan skala bau pada perlakuan dengan waktu inkubasi 48 jam, 72 jam, dan 96 jam berturut-turut semakin rendah skala bau yang dihasilkan jika dibandingkan dengan kontrol $\left(\mathrm{K}_{1}, \mathrm{~K}_{2}\right.$, $\mathrm{K}_{3}$ ). Penurunan skala bau $\mathrm{P}_{1}, \mathrm{P}_{2}, \mathrm{P}_{3}, \mathrm{P}_{4}$ (48 jam) yaitu 6, 6, 6, 4 (agak bau, agak bau, agak bau, agak tidak bau) lebih rendah skala baunya dibanding skala bau $\mathrm{K}_{1}$ (48 jam) sebesar 7 (bau). Perlakuan $\mathrm{P}_{5}, \mathrm{P}_{6}, \mathrm{P}_{7}, \mathrm{P}_{8}$ (72 jam) dengan penurunan skala bau 6, 4, 4, 4 (agak bau, agak tidak bau, agak tidak bau, agak tidak bau) lebih rendah dibandingkan skala bau $\mathrm{K}_{2}(72$ jam) sebesar 7 (bau). Perlakuan $\mathrm{P}_{9}, \mathrm{P}_{10}$, $\mathrm{P}_{11}, \mathrm{P}_{12}(96$ jam) dengan penurunan skala bau 4, 4, 4, 3 (agak tidak bau, agak tidak bau, agak tidak bau, tidak bau) lebih rendah skala baunya dibandingkan $\mathrm{K}_{3}(96$ jam) sebesar 7 (bau). Berdasarkan data tersebut, penurunan skala bau pada waktu 48 jam lebih rendah dibandingkan 72 jam dan 96 jam. Kondisi tersebut disebabkan waktu inkubasi 48 jam adalah waktu yang cukup singkat dalam mendeodorisasi limbah cair batik.

Miselium jamur membutuhkan waktu untuk menyesuaikan diri dengan lingkungan, yang menyebabkan tidak terdegradasinya limbah tekstil dalam waktu singkat (Setioningrum, 2005). Kemampuan deodorisasi akan baik jika waktu inkubasi semakin lama. Lamanya waktu inkubasi menyebabkan lamanya hubungan atau kontak limbah cair batik dengan baglog $P$. ostreatus sehingga untuk mendeodorisasi semakin lama. Widodo, (2012) menyatakan semakin lama waktu inkubasi, semakin lama kontak atau hubungan limbah cair batik dengan adsorben dalam proses adsorpsi, sehingga kesempatan rongga pada adsorben untuk menjerap senyawa yang dikandung limbah cair batik juga semakin lama.

Perlakuan $\mathrm{P}_{12}$ menunjukkan penurunan skala bau yang terendah dan diketahui bahwa $\mathrm{P}_{12}$ menggunakan kombinasi $100 \mathrm{ml}$ volume limbah cair batik dan 96 jam waktu inkubasi. $\mathrm{P}_{12}$ yang paling baik dalam mendeodorisasi limbah cair batik berupa penurunan skala bau lebih rendah dibandingkan yang lain sebesar 3 (tidak bau). Hal tersebut disebabkan volume limbah cair batik pada $100 \mathrm{ml}$ teroptimalkan proses adsorpsinya (sistem non-enzimatik). Keberhasilan tersebut diikuti oleh proses absorpsi (sistem enzimatik) dan didukung juga oleh lamanya waktu inkubasi yang diujikan yaitu 96 jam sehingga meningkatkan kemampuan deodorisasi dibandingkan yang lainnya.

\section{B. Persentase Penurunan Nilai BODdan COD Limbah Cair Batik}

Keberhasilan deodorisasi limbah cair batik menggunakan limbah baglog $P$. ostreatus dengan kombinasi volume dan waktu inkubasi berbeda diikuti oleh persentase penurunan nilai BOD dan COD limbah cair batik yang diujikan di 12 perlakuan dan disajikan pada Gambar 4. 


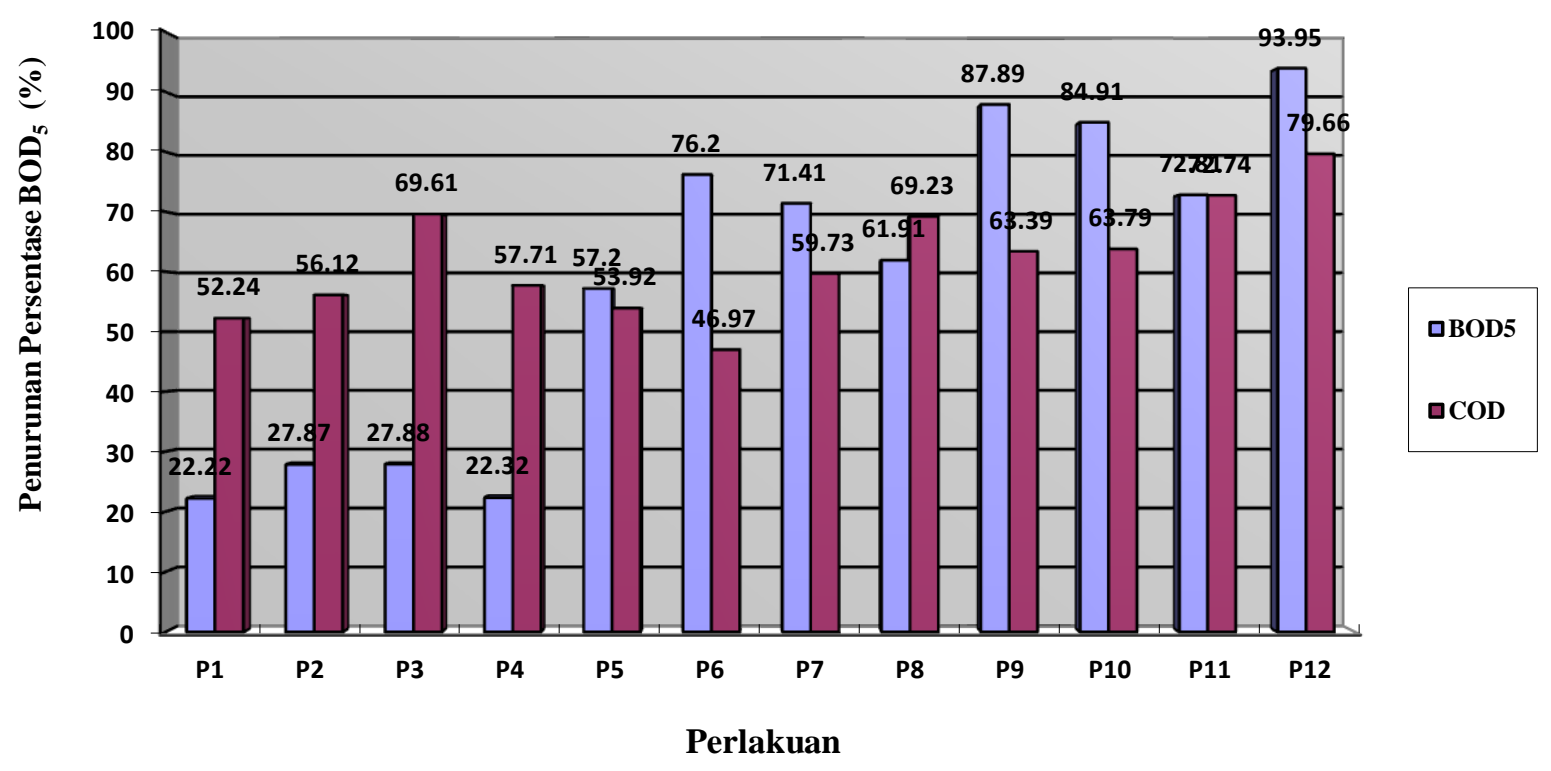

Gambar 4. Kemampuan Deodorisasi Limbah Cair Batik Berupa Persentase Penurunan Nilai BOD dan COD Limbah Cair Batik

Gambar 4 menunjukkan persentase penurunan nilai BOD dan COD limbah cair batik menggunakan limbah baglog $P$. ostreatus dengan kombinasi volume dan waktu inkubasi berbeda. Hasil terbaik persentase penurunan nilai BOD dan COD limbah cair batik sebesar 93,95\% (3301 mg/l menjadi $200 \mathrm{mg} / \mathrm{l})$ dan 79,66\% (15200 $\mathrm{mg} / \mathrm{l}$ menjadi $3120 \mathrm{mg} / \mathrm{l}$ ) pada perlakuan $\mathrm{P}_{12}$. Hasil analisis variansi persentase penurunan nilai BOD dan COD limbah cair batik disajikan pada Tabel 1 .
Berdasarkan analisis variansi, seluruh perlakuan memberi pengaruh yang berbeda sangat nyata pada probabilitas 0,01. Hal tersebut berarti limbah baglog $P$. ostreatus dengan kombinasi volume dan waktu inkubasi berbeda yang digunakan memiliki kemampuan yang signifikan dalam menurunkan nilai BOD dan COD limbah cair batik. Hal tersebut mengindikasikan bahwa penggunaan limbah baglog $P$. ostreatus dengan kombinasi

Tabel 1. Analisis variansi persentase penurunan nilai BOD dan COD limbah cair batikmenggunakan limbah baglog $P$. ostreatus dengan kombinasi volume dan waktu inkubasi berbeda

\begin{tabular}{|c|c|c|c|c|c|c|}
\hline \multirow{2}{*}{ BOD } & \multirow{2}{*}{$\begin{array}{c}\text { Jumlah } \\
\text { Kuadrat }\end{array}$} & \multirow{2}{*}{$\begin{array}{c}\text { Derajat } \\
\text { Bebas }\end{array}$} & \multirow{2}{*}{$\begin{array}{c}\text { Kuadrat } \\
\text { Tengah }\end{array}$} & \multirow{2}{*}{$\begin{array}{c}\text { F } \\
\text { Hitung }\end{array}$} & \multicolumn{2}{|c|}{ F Tabel } \\
\hline & & & & & 0,05 & 0,01 \\
\hline Perlakuan & 9610,473 & 11 & 873,679 & 22923,446 & 2,22 & 3,09 \\
\hline Galat & 0,915 & 24 & 0,038 & & & \\
\hline Total & 9611,388 & 35 & & & & \\
\hline \multirow{2}{*}{ COD } & \multirow{2}{*}{$\begin{array}{c}\text { Jumlah } \\
\text { Kuadrat }\end{array}$} & \multirow{2}{*}{$\begin{array}{c}\text { Derajat } \\
\text { Bebas }\end{array}$} & \multirow{2}{*}{$\begin{array}{c}\text { Kuadrat } \\
\text { Tengah }\end{array}$} & \multirow{2}{*}{$\begin{array}{c}F \\
\text { Hitung }\end{array}$} & \multicolumn{2}{|c|}{ F Tabel } \\
\hline & & & & & 0,05 & $\mathbf{0 , 0 1}$ \\
\hline Perlakuan & 1186,937 & 11 & 107,903 & 23,662 & 2,22 & 3,09 \\
\hline Galat & 109,445 & 24 & 4,560 & & & \\
\hline Total & 1296,382 & 35 & & & & \\
\hline
\end{tabular}


volume dan waktu inkubasi berbeda mampu mendegradasi polutan organik dan komponen fenolik pada limbah cair batik. Namun penurunan nilai BOD dan COD limbah cair batik yang diujikan tersebut belum memenuhi baku mutu limbah cair tekstil dan batik yang telah ditetapkan oleh Pemerintah Jawa Tengah. Ketetapan tersebut tertuang pada Keputusan No.5 Tahun 2012 No.5 Tahun 2012 untuk BOD yaitu sebesar $60 \mathrm{mg} / \mathrm{l}$ dan COD sebesar $150 \mathrm{mg} / \mathrm{l}$. Walaupun demikian nilai tersebut telah berhasil menunjukkan adanya penurunan nilai BOD dan COD limbah cair batik menggunakan limbah baglog P. ostreatus dengan kombinasi volume dan waktu inkubasi berbeda dibandingkan nilai BOD awaldan COD awal. Hasil uji BNJ disajikan pada Tabel 2.

Hasil persentase uji BNJ pada Tabel 2 menunjukkan bahwa variasi volume dan waktu inkubasi berbeda, berpengaruh terhadap persentase penurunan nilai BOD dan COD limbah cair batik dalam proses deodorisasi dengan hasil berbeda di 12 perlakuan. Persentase penurunan nilai BOD dan COD limbah cair batik pada perlakuan
$\mathrm{P}_{1}-\mathrm{P}_{4}$ berkisar $28,07-31,87 \%$ dan 46,19$52,92 \%$. Persentase penurunan nilai BOD dan COD limbah cair batik pada perlakuan $\mathrm{P}_{5}-\mathrm{P}_{8}$ berkisar 49,24-60,57\% dan $43,24-56,41 \%$. Persentase penurunan nilai BOD dan COD limbah cair batik pada perlakuan $\mathrm{P}_{9}-\mathrm{P}_{12}$ berkisar 58,57$75,75 \%$ dan 52,50-63,13\%. Hasil persentase uji BNJ terbaik untuk BOD dan COD limbah cair batik diperoleh pada perlakuan $\mathrm{P}_{12}$ dengan persentase penurunan nilai BOD dan COD limbah cair batik sebesar $75,75 \%$ dan $63,13 \%$.Persentase penurunan nilai BOD dan COD limbah cair batik disebabkan adanya proses adsorpsi (aktivitas nonezimatik) dan absorpsi (aktivitas enzimatik). Proses tersebut menyebabkan persentase penurunan nilai BOD dan COD limbah cair batik. Menurut Firdus dan Muchlisin, (2010) dalam Doraja et al., (2012) prinsip pemanfaatan aktivitas mikroorganisme dalam pengolahan limbah adalah merombak limbah tersebut menjadi senyawa yang lebih sederhana atau tidak toksik dan mengkonversinya menjadi gas $\mathrm{CO}_{2}, \mathrm{H}_{2} \mathrm{O}$ dan energi untuk pertumbuhan dan reproduksinya.

Tabel 2. Uji BNJ pengaruh limbah baglog P. ostreatus dengan kombinasi volume dan waktu inkubasi berbeda terhadap persentase penurunan nilai BOD dan COD limbah cair batik

\begin{tabular}{|c|c|c|c|}
\hline No. & Perlakuan & $\begin{array}{c}\text { Rata-rata persentase } \\
\text { penurunan nilai BOD }(\boldsymbol{\%})\end{array}$ & $\begin{array}{c}\text { Rata-rata persentase } \\
\text { penurunan nilai COD }(\boldsymbol{\%})\end{array}$ \\
\hline 1. & $\mathrm{P}_{1}$ & $28,07 \mathrm{a}$ & $46,19 \mathrm{ab}$ \\
\hline 2. & $\mathrm{P}_{2}$ & $31,85 \mathrm{~b}$ & $48,50 \mathrm{ab}$ \\
\hline 3. & $\mathrm{P}_{3}$ & $31,87 \mathrm{~b}$ & $52,92 \mathrm{bcde}$ \\
\hline 4. & $\mathrm{P}_{4}$ & $28,18 \mathrm{a}$ & $49,41 \mathrm{abc}$ \\
\hline 5. & $\mathrm{P}_{5}$ & $49,24 \mathrm{c}$ & $47,14 \mathrm{ab}$ \\
\hline 6. & $\mathrm{P}_{6}$ & $60,57 \mathrm{~g}$ & $43,24 \mathrm{a}$ \\
\hline 7. & $\mathrm{P}_{7}$ & $57,64 \mathrm{e}$ & $50,56 \mathrm{abcd}$ \\
\hline 8. & $\mathrm{P}_{8}$ & $51,78 \mathrm{~d}$ & $56,41 \mathrm{cdef}$ \\
\hline 9. & $\mathrm{P}_{9}$ & $69,88 \mathrm{i}$ & $57,37 \mathrm{def}$ \\
\hline 10 & $\mathrm{P}_{10}$ & $67,08 \mathrm{~h}$ & $52,50 \mathrm{bcd}$ \\
\hline 11 & $\mathrm{P}_{11}$ & $58,57 \mathrm{f}$ & $60,26 \mathrm{ef}$ \\
\hline 12 & $\mathrm{P}_{12}$ & $75,75 \mathrm{j}$ & $63,13 \mathrm{f}$ \\
\hline
\end{tabular}

Keterangan : Angka dengan huruf yang sama tidak memiliki perbedaan yang signifikan pada BNJ 1\%. Data dalam uji BNJ telah ditransformasikan ke dalam $\operatorname{arc} \sin \sqrt{x}$. 
Carolina dan Neli, (2012) menjelaskan penurunan COD semakin rendah ketika jumlah sel cenderung bertambah. Menurut Achmad dan Atikalidia, (2011)

pertumbuhan populasi mikroorganisme berpengaruh penting terhadap efisiensi proses penyisihan nilai COD. Jenie dan Rahayu, (1993) dalam Doraja et al., (2012) juga menjelaskan kebanyakan mikrooganisme menggunakan bahan organik sebagai sumber energi dan karbon, sehingga berperan penting dalam penanganan limbah cair karena dapat mendegradasi bahan organik.

Proses deodorisasi juga dipengaruhi oleh nilai $\mathrm{pH}$ dan suhu limbah cair batik. Nilai $\mathrm{pH}$ limbah cair batik awal adalah 7, sedangkan nilai $\mathrm{pH}$ akhir berkisar antara $6-8$. Yuniawati, (2006) menjelaskan kondisi $\mathrm{pH} 7$ berfungsi dalam mengaktifkan enzim, berperan dalam produksi energi formasi protein dan replikasi sel pada jamur. Aziziah, (2008) menambahkan jamur akan tumbuh baik pada kisaran $\mathrm{pH}$ 4-7. Berdasarkan hal tersebut, adanya perubahan $\mathrm{pH}$ menunjukkan kerja enzim sebagai aktivitas metabolisme yang memungkinkan adanya kemampuan deodorisasi dan menurut Pemprov Jateng, (2012) masih dalam batas ambang baku mutu limbah cair batik yang ditetapkan oleh pemerintah dengan kisaran pH 6-9.

Berdasarkan pengukuran suhu diketahui bahwa nilai suhu pada awal perlakuan yaitu sebesar $28{ }^{\circ} \mathrm{C}$ dan mengalami peningkatan suhu pada akhir perlakuan berkisar antara 29-32,3 ${ }^{\circ} \mathrm{C}$. Menurut Aziziah, (2008) adanya perubahan suhu disebabkan karena kerja enzim sebagai aktivitas metabolisme yang menandai adanya kemampuan mikroorganisme dalam mengolah limbah.

Peningkatan suhu yang terjadi diduga menunjukkan bahwa miselium $P$. ostreatus yang terdapat pada limbah baglog $P$. ostreatus mempengaruhi proses deodorisasi melalui aktivitas enzimatiknya. Menurut Campbell et al., (2002) bahwa suhu adalah salah satu faktor penting dalam aktivitas suatu enzim sampai pada suatu titik, kecepatan suatu reaksi enzimatik meningkat sejalan dengan meningkatnya suhu. Menurut Djariyah dan Djariyah, (2011) miselium $P$. ostreatus tumbuh optimal pada suhu 25-30 ${ }^{\circ} \mathrm{C}$. Menurut Pemprov Jateng, (2012) kisaran suhu yang didapatkan pada kelompok perlakuan yang diujikan masih berada dibawah baku mutu suhu limbah cair batik yang ditetapkan oleh pemerintah sebesar $38{ }^{\circ} \mathrm{C}$.

\section{KESIMPULAN}

1. Penggunaan limbah baglogP. Ostreatus dengan kombinasi volume dan waktu inkubasi berbeda mampu mendeodorisasi limbah cair batik.

2. Perlakuan dengan kombinasi limbah baglog $P$. ostreatus $25 \mathrm{~g}$, volume limbah cair batik $100 \mathrm{ml}$ dengan waktu inkubasi 96 jam adalah perlakuan yang paling baik dalam mendeodorisasi limbah cair batik.

\section{Daftar Pustaka}

Achmad, S.A dan M. Atikalidia. 2011. Penyisihan Chemical Oxygen Demand (COD) dan Produksi Biogas Limbah Cair Pabrik Kelapa Sawit dengan Bioreaktor Hibrid Anaerob Bermedia Cangkang Sawit. Prosiding Seminar Nasional Teknik Kimia Kejuangan ISSN, Vol. 1, 1693 4393.

APHA. 1995, Standar Method For The Examination of Water and Wastewater, 18th Ed. American Public Healt Association, Washington D.C.

Astirin, O.P dan K. Winarno. 2000. Peran Pseudomonas dan Khamir dalam Perbaikan Kualitas dan 
Dekolorisasi Limbah Cair Industri Batik Tradisional.BioSMART, Vol. 2, No. 1, 13-19.

Atkins. 1999. Kimia Fisik Jilid I Edisi Ke-4. Erlangga, Jakarta.

Awaludin, R., Darah, I., Ibrahim, C.O and A.M. Uyub. 2001. Decolorization of Commercially Available Synthetic Dyes By TheWhite Rot Fungus Phanerochaete chrysosporium. J Fungi and Bactery, Vol. 62, 55 63.

Aziziah, R. N. 2008. Deodorisasi Limbah Lateks Pekat dan Dekolorisasi Zat Pewarna Tekstil Secara Enzimatis Dengan Formula Omphalina sp. Skripsi (tidak dipublikasi).Fakultas Matematika dan Ilmu Pengetahuan Alam. Institut Pertanian Bogor, Bogor.

Bonnen, A.M., Anton, L.H and A.B. Ort. 1994. Lignin-Degrading Enzymes Of The Commercial Button Mushroom, Agaricus bisporus. Appl. Environ. Microbiol, Vol. 60, 960-965.

Budiawan.2001. Pengkajian KeputusanMenteri Lingkungan Hidup No.50/MenLH/II/1996 Tentang Resiko danKeselamatan Lingkungan.(Laporan penelitian). Depok:Fakultas Matematika dan Ilmu Pengetahuan Alam. Universitas Indonesia, Jakarta.

Campbell, N.A., Reece, J.B., and L.G. Mitchell.2002. Biologi Edisi Kelima Jilid I. Penerbit Erlangga, Jakarta.

Carolina, S dan Neli. 2012. Netralisasi Limbah Karet Oleh Beberapa Jenis Mikroalga. Prosiding Seminar Perhimpunan Bioteknologi Pertanian Indonesia Pusat Penelitian dan Pengembangan Fisika Terapan LIPI, Vol. 1, No. 1, 433-439.
Choi, J.J. 1997. Oxidative Removal Of Maladorous Volatile Sulfur Compounds By Air Over A Activated Carbon Fiber. Journal of Ind. \& Eng. Chemistry, Vol. 3 No. 1, 56-62.

CPCB. 2008. Guidelines On Odour Pollution and Its Control. Central Pollution Control Board, New Delhi.

De Jong, J.A., Field, and J.A.M. de Bont. 1994. Aryl Alcohols In The Physiology Of Ligninolytic Fungi. FEMS Microbiol Reviews, Vol. 13, No. 1, 153-188.

Dhouib. 2005. Autochthonous Fungal Strains With High Ligninolytic Activities From Tunisian Biotopes. African J of Biotechnol, Vol. 4, No. 5, 431-436.

Doraja, P.H., Shovitri, M dan N.D. Kuswytasari. 2012. Biodegradasi Limbah Domestik Menggunakan Inokulum Alami Dari Tangki Septik. Jurnal Sains dan Seni ITS, Vol. 1, No. 1, 44-47.

Djariyah, N.M dan A.S. Djariyah. 2001. Budidaya Jamur Tiram: Pembibitan Pemeliharaan dan Pengendalian Hama Penyakit. Penerbit Kanisius, Yogyakarta.

Groff, K.A. 1991. Textile Waste. Research Journal WPCF, Vol. 63, No. 4, 459-462.

Hatakka,A.1994. Lignin Modifying Enzyme FromSelected White Rot Fungi: Production and Role In Lignin Degradation. FEMS Microbiol. Rev, Vol. 13, No. 1, 125-135.

Hedge, M.S and P. Berra. 2002. Oxidation and Decomposition Of $\mathrm{NH}_{3} \quad$ Over Combustion Synthesized $\mathrm{Al}_{2} \mathrm{O}_{3}$ and $\mathrm{CeO}_{2}$ Supported Pt, Pd and $\mathrm{Ag}$ Catalysts. Indian Journal of 
Chemistry, Vol. 41 A, 1554 1561.

Howard, R., Abotsi, L., Rensburg, E.J van E., Howard, $S$ dan L. Howard. 2003. Lignocellulose Biotechnology: Issues OfBioconversion and Enzyme Production. African $J$ of Biotechnol, Vol. 2, 602-619.

Kasam, A., Yulianto dan A. E. Rahmayanti. 2009. Penurunan COD dan Warna Pada Limbah Cair Industri Batik Dengan Menggunakan Aerobic Roughing Filter Aliran Horizontal. Logika, Vol. 6, No. 1, 27 - 31.

Kosasih, H. 2003. Studi Deodorisasi Pada Lateks Secara Mikrobiologi MenggunakanIsolat Bakteri. Skripsi (tidak dipublikasikan).Fakultas

Matematika dan Ilmu Pengetahuan Alam. Universitas Indonesia, Jakarta.

Malik, A. 2003. Analisis Sistem Pengelolaan Industri Tekstil Dalam Upaya Meminimisasi Limbah Cair Di Kota Medan. Tesis (dipublikasikan). Program Pascasarjana Universitas Sumatera Utara, Medan.

Mufrodi, Z.N., Widiastuti dan R.C. Kardika. 2008. Adsorpsi Zat Warna Tekstil Dengan Menggunakan Abu Terbang (Fly Ash) Untuk Variasi Massa Adsorben dan Suhu Operasi. Proseding Seminar Nasional Teknologi Industri Bidang Teknik Kimia dan Tekstil, Yogyakarta.

Nasreen, Z., B. Rukhsana dan K. Tasnim. 2007. Decolorization OfTextile Dyes and Their Effluents Using White Rot Fungi. Mycopath, Vol. $5,49-52$.

Negishi, O dan Y, Negishi. 1999. Enzymatic Deodorization With
Raw Fruits, Vegetables and Mushroom. Food Sci. Technol. Res, Vol. 5, No.2, 176-180.

Negishi, O., Negishi, Y dan T. Ozawa. 2000. Enzymatic Deodorization With Variegatic Acid FromBoletus subvelutipes and Its Mechanism. Food Sci. Technol. Res, Vol. 6, No.3, 186-191.

Palmieri, G., Giardina, P., Bianco, C., Fontanella, B and G. Sannia. 2000. Copper Induction Of Laccase Isoenzymes In The Ligninolytic Fungus Pleurotus ostreatus.Apllied and Environmental Microbiology, Vol. 66, No. 3, 920-924.

Pemerintah Provinsi Jateng. 2012. Peraturan Daerah Provinsi Jawa Tengah Nomor 5 Tahun 2012 Tentang Baku Mutu Air Limbah Untuk Kegiatan Industri, Semarang.

Rani, C., Asim, K.J., dan B, Ajay. 2011. Studies On Biodegradation Of Azo Dyes By White Root Fungi Daedalea flavidaIn The Absence OfExternal Carbon Source. 2nd International Conference on Enviromental Sicience and Technology. IACSIT Press,Singapore.

Rambe, A.M., 2008. Pemanfaatan Biji Kelor (Moringa oleivera) Sebagai Koagulan Alternatif Dalam Proses Penjernihan Limbah Cair Industri Tekstil. Tesis (dipublikasikan). Program Pascasarjana Universitas Sumatera Utara, Medan.

Romsiyah. 2012. Pengaruh Bobot Massa Limbah Medium Tanam Jamur Pleurotus ostreatus Terhadap Daya Dekolorisasi Limbah Batik. Laporan penelitian Student Grant IM-HERE (tidak dipublikasikan). Fakultas Biologi Universitas Jenderal Soedirman, Purwokerto. 
Rosdiana, T. 2006. Pencirian dan Uji Aktivitas Katalitik Zeolit Alam Teraktivasi.Skripsi

(dipublikasikan).Departemen

Kimia Fakultas Matematika dan Ilmu Pengetahuan Alam Institut Pertanian Bogor, Bogor.

Santoso, S. 2002. Statistik Nonparametrik Konsep dan Aplikasi Dengan SPSS. Penerbit Elex Media Komputindo, Jakarta.

Setioningrum, Y. 2005. Biodegradasi Pewarna Direct Red (Azo) Menggunakan Beberapa Fungi Pelapuk Putih Dengan Waktu Inkubasi Berbeda. Skripsi (tidak dipublikasikan). Fakultas Biologi Universitas Jenderal Soedirman, Purwokerto.

Sigit, A.M. 2008. Pola Aktivitas Enzim Lignolitik Jamur Tiram (Pleurotus ostreatus)PadaMedia Sludge Industri Kertas. Skripsi (dipublikasikan).Program Studi Biokimia Fakultas Matematika dan Ilmu Pengetahuan Alam Institut Pertanian Bogor, Bogor.

Singh, H. 2006. Mycoremediation Fungal Bioremediation.John willey \& sons Inc., New Jersey.

SNI-06-6989.11. 2004.Air dan Limbah Bagian 11: Cara Uji Derajat Keasaman $\quad(\mathrm{pH})$ Dengan Menggunakan $\mathrm{pH}$ meter. Badan Standardisasi Nasional, Jakarta.

SNI-06-6989.23. 2005. Air dan Limbah Cara Uji Suhu Menggunakan Termometer. Badan Standardisasi Nasional, Jakarta.

SNI-01-2346.2006. Petunjuk Pengujian Organoleptik atau Uji Sensori. Badan Standarisasi Nasional, Jakarta.

Sokal, R.R. and F.J.Rohl. 1981. Biometry : The Principle and Practise Of Statistic In Biological Research. 2nd edition. W. H. Freeman Company, New York.

Sorta, R.R.T. 2013.Penyerapan Zn dan Dekolorisasi Beberapa Macam Limbah Cair Batik Menggunakan Limbah Baglog Pleurotus ostreatusDengan Waktu Inkubasi Berbeda.Skripsi (tidak dipublikasikan). Fakultas Biologi Universitas Jenderal Soedirman, Purwokerto.

Sukarta, I. N, 2008. Adsorpsi Ion $\mathrm{Cr}^{3+}$ Oleh Serbuk Gergaji Kayu Albazia (Albizzia falcate): Studi Pengembangan Bahan Alternatif Penyerap Limbah Logam Berat. Tesis (dipublikasikan). Sekolah Pascasarjana Institut Pertanian Bogor, Bogor.

Suwarsa, S. 1998. Penyerapan Zat Warna Tekstil BR. Red HE 7B Oleh Jerami Padi. JMS, 3(1): 32-40.

Tamaki, K., Tamaki, T dan T. Yamazaki. 2007. Studies On Deodorization By Mushroom (Agaricus bisporus)ExtractOf GarlicInduced Oral Malodor. J Nutr Sci Vitaminol, 53(1): 277-286.

Tavcar, M. 2006. Biodegradation Of Azo Dye RO16 In Different Reactors By Immobilized Irpex Lacteus. Acta Chim Slov, 53 (1) : 338-343.

Thurston CF. 1994. The Structure and Function OfFungal Laccase. Journal Microbiology, Vol. 140, 19 - 26.

Widodo, E. 2012. Kajian Eksperimental Efektifitas Arang Aktif Mesh 40 Dari Limbah Serbuk Penggergajian Kayu Jati Dalam Penyerapan Polutan Limbah Cair Dari Industri Batik Di Tamansari Yogyakarta. Artikel Ilmiah Tugas Akhir (dipublikasikan). Fakultas Teknik Universitas Muhammadiyah Yogyakarta, Yogyakarta. 
Yasuda, $\mathrm{H}$ dan T, Arakawa. 1995. Deodorizing Mechanism Of (-)Epigallocatechin Gallate Methyl Mercaptan.Biosci.Biotech.Bioche $m$, Vol. 59, No. 7, 1232-1236.

Yaropolov, A.I., Skorobogatko, O.V., Vartanov, S.S and S.D. Varvolomeyev. 1994. Catalytic Mechanism of Laccase. $J$ Biochem and Biotechnol, Vol. 49, 257-280.
Yuniawati, S. 2006. Optimasi Media dan Inokulum Jamur Pelapuk Putih Untuk Pengomposan TKKS. Skripsi (tidak dipublikasi). Fakultas Matematika dan Ilmu Pengetahuan Alam Univeritas Pakuan, Bogor. 